\title{
CITIZENSHIP AND CONVIVENCIA
}

EDUCATION IN CONTEXTS OF

VIOLENCE: TRANSNATIONAL

CHALLENGES TO PEACEBUILDING EDUCATION IN MEXICAN SCHOOLS

\author{
Educación ciudadana y convivencia en contextos de \\ violencia: desafíos transnacionales a la construcción de \\ paz en escuelas de México
}

Diego Nieto and Kathy Bickmore *

\section{ABSTRACT}

Education for sustainable peacebuilding citizenship requires opportunities to examine and democratically handle social conflicts. In this light, this paper examines teachers' understandings of social conflicts, and their reported implemented curriculum, based on a series of focus group workshops with 5-6 teachers in each of three schools in marginalized, violent neighborhoods in one Mexican city. Teachers identified a variety of conflicts affecting their students, including direct violence (domestic/gendered, gangs, bullying) and structural conflicts (emigration, pollution, drug trafficking, unemployment, labor exploitation). These conflicts' transnational dimensions were generally not

\footnotetext{
${ }^{*}$ University of Toronto (Canadá).
} 
acknowledged. We argue that the imaginaries of conflict and democratic action shaping participants' teaching practices are influenced by neoliberal discourses of citizenshipdetached from transnational social structural dynamics, with causal explanations and solution alternatives limited to individual values choices. Such a narrow, security-oriented approach to citizenship and convivencia education would function to govern marginalized populations more than to enhance democratic agency. We highlight some promising instances of dialogue and collective action lessons addressing equity through conflict issues, as windows of possibility for development of democratic peacebuilding agency in the face of pervasive transnational social conflicts and violence.

KEY WORDS: Citizenship Education, Global Education, Social Problems, Peace Education.

\section{RESUMEN}

La educación para la ciudadanía y la construcción de paz sostenible implica oportunidades de estudiar y tramitar conflictos sociales de manera democrática. El presente artículo examina las comprensiones que diferentes docentes tienen sobre los conflictos sociales que afectan a sus estudiantes y el currículo implementado por ellos en relación a la convivencia y la ciudadanía. Se sustenta en una serie de grupos focales con grupos de 5-6 maestros en tres escuelas ubicadas en barrios marginados afectados por la violencia de una ciudad en México. Los participantes identificaron una variedad de conflictos relevantes, desde formas de violencia directa (doméstica/de género, pandillas, bullying) hasta conflictos estructurales (emigración, contaminación, tráfico de drogas, desempleo, explotación laboral) que afectan a sus estudiantes. En general, las dimensiones transnacionales de estos conflictos fueron ignoradas por los maestros. Argumentamos que las comprensiones sobre estos conflictos y los imaginarios de agencia democrática presentes en las prácticas de enseñanza de los participantes se encuentran influenciados por discursos neoliberales sobre la ciudadanía. Éstos limitan las explicaciones y alternativas de solución de los conflictos sociales a decisiones individuales, separándolas de las dinámicas sociales estructurales y transnacionales que los enmarcan. Este enfoque restringido de la educación ciudadana y la convivencia, orientado hacia la promoción de la seguridad, funcionaría más como forma de gobierno de poblaciones marginadas que para potenciar las capacidades de agencia democrática. Destacamos, en contraste, algunos ejemplos prometedores de lecciones donde estos maestros, orientados por el diálogo y la acción colectiva, buscan objetivos de equidad mediante el abordaje de asuntos conflictivos. Tales ejemplos representan ventanas de posibilidad para el desarrollo de formas de enseñanza democrática para la construcción de paz, que dan cuenta de las complejas formas de violencia contemporánea incluyendo su escala trasnacional. 
PALABRAS CLAVE: Educación Ciudadana, Educación Global, Conflicto Social, Educación para la Paz.

$* * * * *$

\section{INTRODUCTION}

In Latin America, as elsewhere, citizenship education programming is promoted as a measure to overcome weak social capital, disaffection, and disengagement of the population from democratic institutions and collective action to resolve public issuespolitical cultures seen as threatening social stability and contributing to escalated violence (COX et al., 2005). Contemporary scholars argue that addressing such challenges requires a broadened, democratic citizenship education approach. This entails democratic pedagogies concerned not merely with transmission of knowledge, values, and master nationalist narratives, but also with building skills and action capacity for handling globalized social conflicts, through dialogic interaction among teachers, texts and students. Further, such democratic citizenship education demands alignment with students' cultural contexts and lived experiences, to enhance youth's access to understanding and opportunities for engaging in meaningful civic activity (CARRETERO et al., 2016). While curricular reforms in Latin America have attempted to move in this direction, few studies have inquired about how practicing teachers understand or implement democratic civic action approaches, or on how they incorporate students' experiences and lived concerns around conflict issues in their learning activities (COX et al., 2014; REIMERS, 2007).

We assume that education for engaged democratic citizenship and sustainable peacebuilding requires that students have opportunities to examine, discuss and take action upon the transnational-structural dimensions of lived social conflicts (BICKMORE, 2014a; DAVIES, 2008). Often, citizenship curricula renders global dimensions of conflicts and citizenship virtually invisible. This constitutes a type of 'global citizenship education:' an imaginary about local communities' and citizens' relationships with transnational forces and with decision-making around globalized problems. Critical decolonial approaches to global citizenship education have argued, resisting ethnocentrism and global hegemony demands questioning ahistorical and depoliticized representations of locally felt, transnationally structured problems with powerful roots in the global North. Andreotti (2015) sustains that, "education should help people in the task of learning to 'go up the river' to the roots of the problem, so that the emergency strategies down the river can be better informed..." (p.229).

Yet, Andreotti's framework of decolonial global citizenship education attends to the contradictions embedded in 'soft' approaches for privileged learners in the global North. Her critique of global citizenship education reproduction of global North-South (colonial) 
inequities, does not differentiate learners' positionality in global citizenship action and curricula. This paper, in contrast, examines global citizenship education that, while not necessarily calling itself global, expresses localized-global citizenship spheres down-river, in the global South. It follows Iris Marion Young (2011) argument that political action responsibilities to fight social injustices vary depending on the positions, privileges, interests, and collective resources people hold in the global structures that shape the transnational character of contemporary injustices.

We argue that global citizenship education, besides attending to transnational structures of power and their historical and ethnocentric character, also has to provide means for youth to understand theirs and others' positions in global social conflicts that shape their lived experiences of citizenship. Otherwise, students (and teachers) who suffer the injustices of those structures will be left frustrated by the burden of curricular demands to be 'good citizens,' overwhelmed by the scarcity of resources and power to challenge large-scale structures involved in social conflicts. This is to say that demands for youth engagement in global citizenship education in marginalized world spaces, needs to first locate such curricular demands in the lived geographies of citizenship amid globalization.

With that in mind, this paper examines sixteen teachers' understandings and practices of citizenship education, in marginalized neighborhoods in one Mexican urban area. Participant schools' neighborhoods are underprivileged spaces, suffering from socioeconomic marginalization when compared to their surroundings. This comes along with class, race and cultural related stigmatization due to crime rates and incidents involving gang and other types of violence. These neighborhoods occupy marginal areas of the city, shaped by rural-urban migrations, working class settlements growing around industrial factories, and rural borders progressively being co-opted by urban expansion.

This work is part of a larger ongoing international comparative project probing the (mis)fit between young people's lived citizenship experiences, in non-affluent local contexts surrounded by violence and their school-based opportunities to develop democratic peacebuilding capacities. Based on a series of focus groups with teachers in each of three schools, we outline the ways participating teachers viewed social conflict problems they identified in the contexts where they taught, then what and how they taught about citizenship to create peace in relation to these conflicts. We aim to illuminate the ways in which the teachers themselves saw their role(s), and their sense of their own and their students' agency, in mitigating locally relevant social conflict problems. Likewise, we examine teachers' implemented curriculum, and the ways they guided students' (dis)engagement in mitigating locally felt, transnationally influenced, social conflicts. Overall, we explore the spaces for furthering (or impeding) globalized democratic peacebuilding citizenship education in these Mexican classrooms. 


\section{LIVED DEMOCRATIC CITIZENSHIP AND SCALED CONFLICTS}

A key assumption underlying this research is that effective citizenship education needs to take into account the actual experiences of youth with regards to social conflicts, and enacted and intended citizenship action (potential peacebuilding politics) in relation to those conflicts. We view conflict, and opportunities to engage in peaceful/democratic resolution of differences including contesting injustices, as the heart of building sustainably peaceful democratic relations. This as an alternative to the traditional notion that citizen engagement is only valuable in order to build social capital, social cohesion, and stability in a functioning democratic system. Participation and engagement are not democratic until they bring opportunities for collectivities to address systemic shortcomings with regards to justice, creating means to engage with conflicts and differences. For us, conflict is not a negative force threatening democratic relations but rather the energy that keeps them alive and creative (BICKMORE, 2014b; BIESTA, 2009; NIETO, 2012a; RUITENBERG, 2010).

Rob Nixon (2011) has coined the term slow violence to refer to the incremental character of large-scale instances of harm to marginalized people and ecosystems in global times. Nixon points to the transnational and inter-generational features that render invisible forms of harm such as global climate change, toxic drifts, deforestation, the radioactive aftermaths of wars, and oil spills. These constitute violence, he argues, only noticed and experienced by the poor on the periphery of the global system. Thus, Nixon updates Galtung's (1969) concept of structural violence, building in the crucial elements of temporality and globalized scale, to understand the escalating intractability of contemporary forms of violence targeting the 'disposable poor.' Such incremental, initially invisible slow violence presents formidable representational obstacles that hinder people's efforts to mobilize for change' to stave off or at least retard the harm inflicted by globalizing forces (NIXON, 2011). With Nixon, we argue that rendering such conflicts (including their transnational dimensions) visible as violence is essential to animate and ground democratic peacebuilding education relevant to marginalized young people's lived experience.

For our analysis of these social conflicts, we use Ross' framework (2010), who suggests differentiating between conflicts provoked by socially-structured interests competing over tangible wants and needs, and those related to psycho-cultural narratives and interpretations, meaning conflicting parties' values and beliefs about how and why some things are important to them, and whom they fear or trust. In addition, due to schoolbased research participants' constant reference to forms of direct violence (often unclearly linked to underlying conflict issues), we include this as a separate analytical category. Similarly, in early phases of the research, problems related to government and authoritiesineffectiveness and abuse of power-emerged as a further category in need of separate analytical consideration (BICKMORE et al., 2017). 


\section{ADDRESSING CONFLICTS THROUGH (GLOBAL) CITIZENSHIP EDUCATION AND CONVIVENCIA}

In Latin America there is considerable ambiguity and contradiction about the status of conflict within citizenship education, complicated by contexts of elevated violence and social-economic inequality (ACEVEDO RODRIGO AND LÓPEZ CABALLERO, 2012; GUEVARA NIEBLA, 2012; IEP, 2015). The emergence of convivencia (peaceful coexistence) discourses within citizenship education addresses concerns about conflict and violence, but leaves room for enormously differing understandings of the role of conflict in educational interactions. Notions of convivencia fall along a continuum between two basic types. One end of this discursive continuum is a narrow sense of controlled convivencia based on seguridad ciudadana (citizen security). Citizen security, like national security, frames the state as protector and legitimizes state authority to guarantee social cohesion. It understands bad choices by 'bad' individuals (and groups) as sources of social conflict and violence, and emphasizes government surveillance and (overt and covert) force for peacekeeping control. Certain social groups, such as youth or drug dealers, are represented as a threat such that "the policies of seguridad ciudadana implicitly exclude them" from social acceptance and democratic citizenship (PEETZ, 2011). As such, citizen security ignores the global, framing the 'threats' of violence as internal-protection of some (deserving) citizens from other (undeserving) residents of the same communities.

Harsh discipline regimes in schools are a kind of citizen security approach to convivencia that implicitly teach a disengaging, authoritarian form of citizenship (CHÁVEZ ROMO, 2014). A young person's learning of citizenship, in a regime emphasizing citizen security, would encourage compliance and legitimize the use of force against 'deviants.' Young people experiencing social exclusion or punitive restriction live different 'citizenship' roles in relation to social conflicts, compared to peers with more autonomy, inclusion, and/or high status (BICKMORE \& MACDONALD, 2010).

An emphasis on risk avoidance and individual responsibility, as O'Malley (1996) argues based on Foucault's theory, represents a neoliberal 'governmentality' to tackle crime. In this view, crime control depends on promoting compliant self-control from the responsible individual, and on policing risk environments (such as poor neighborhoods) for surveillance, often using non-traditional securitization actors such as teachers or private security (NIETO, 2012b). The extension of zero tolerance policies and anti-bullying lawsin particular the recent, strict control oriented Convivencia law in Guanajuato and other Mexican states (ZURITA RIVERA, 2013)-has placed school personnel in charge of extending this chain of security. Such safe schools initiatives reinforce inequities and control more than empowering or addressing underlying causes of violent social relations (BICKMORE, 2011a, 2011b; HAKVOORT \& OLSSON, 2014; MORRISON AND VAANDERING, 2012). 
Iris Marion Young argues, these measures have been legitimized through shifts towards an individual 'blame' model of responsibility in social policy. A discourse attuned with the narrow, citizen security approach to convivencia described above. As she explains, discourses of 'personal responsibility' became prominent concurrently with neoliberal welfare reforms and public service cutbacks since 1990s. This discourse assumes that each individual/family has its own sphere of responsibility into which they ought to internalize all the costs-such as competing to find work-for their own welfare. Such discourses of personal responsibility: 1) blame one citizen in order to absolve others (and the collective, represented by government) for social problems; 2) invisibilize large-scale social structural and transnational processes in assessing people's responsibility for their circumstances; and 3) unfairly burden the poor as the 'irresponsible' whom the 'public' needs to worry about (YOUNG, 2011). The risk of reproducing such understandings in schools is exacerbated by the paradox that even education for social change is presumed to act essentially on the individual learner.

Drawing on Young and Nixon, we argue that in neoliberal approaches to citizenship curricula slow violence phenomena such as global inequality, de-industrialization, precarious work and low wages, domestic violence, pollution, and migration become invisible as products of global dynamics, reducing opportunities for understandings of collective action alternatives. Due to the scale and predominantly individual views on these social injustices, people may not feel required to, or capable of, doing anything to change these social conflict patterns. As participating teachers reiterated to us, 'but what can I do?' People often do not see these social harms as the consequence of their own actions, nor how they can be transformed by collective political action.

The other end of the continuum - an entirely different way in which convivencia might be interpreted and implemented-involves mutually respectful, peaceful relationships among diverse people living together in communities (DÍAZ-AGUADO, 2002; FIERRO et al., 2013). Convivencia democrática (democratic peaceful coexistence) emphasizes human rights, cooperative interaction, and power sharing, and embodies addressing the sources of and solutions to social conflict, including injustice, through mutual engagement across differences, within and beyond schools (CARBAJAL PADILLA, 2013). In a regime emphasizing democratic convivencia, a young person's learning of citizenship might encourage guided practice in autonomous and collective problem solving, as well as addressing and redressing complex and large-scale social structures of injustice - a much more actively, transnationally democratic citizen role than under a citizen security-oriented approach to convivencia. 
Through the prism of conflict theory, citizen security approaches enact peacekeeping, privileging surveillance and control to achieve negative peace, meaning the absence of overt direct violence. Gentler, less overt forms of peacekeeping privilege selfsurveillance and self-control through teaching and internalization of the blame/deficit discourses analyzed by Young (BICKMORE, 2011a, 2011b). In contrast, democratic convivencia approaches aim at peacebuilding, which incorporates peacemaking (nonviolent conflict resolution through dialogue and negotiation) while also aiming to build long term, complex processes of overcoming exploitation and dehumanization, addressing structural inequities and engaging openly with cultural differences-peacebuilding implies the regularized presence of justice and non-violent relationships (GALTUNG, 1976; applied to education, see BICKMORE FORTHCOMING 2017). Figure 1 below summarizes the above conceptual frame.

Figure 1. Alternate Approaches to Convivencia in Citizenship and Peace Education

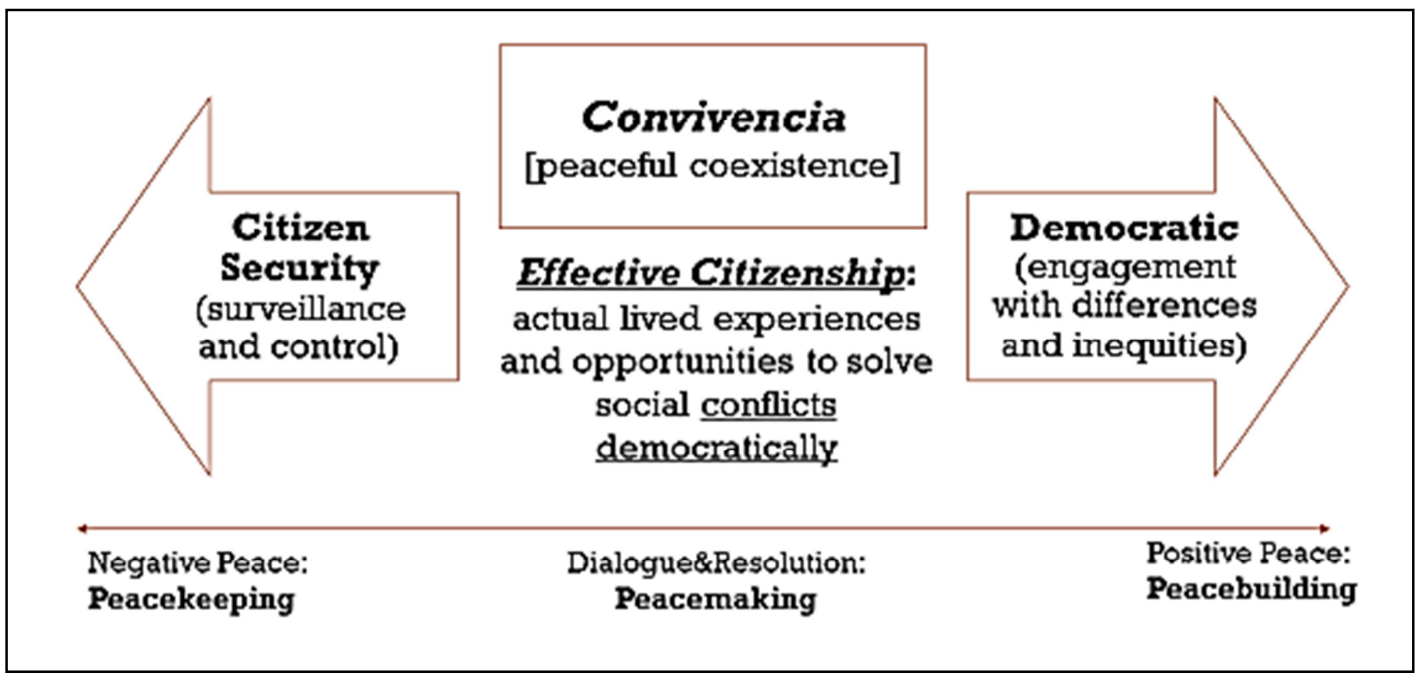

Impulses for citizen security and for democratic convivencia tend to co-exist in plural democratic societies. Lived citizenship experiences inside schools may foster or contradict these different goals of convivencia. In this paper, we explore how selected teachers are implementing these contradicting and overlapping ideals of convivencia, citizenship and peace in their teaching, to identify opportunities for their students to learn about transnational-local social (injustice) conflicts and about potential democratic peacebuilding responses to them. We examine the understandings, feelings, and options teachers shared as relevant to various types of social conflicts, including their (often invisible) transnational dimensions. As such, this work reveals the complexities and contrasting ideals at play when citizenship and convivencia education ideals confront the large-scale social conflicts experienced in marginalized, violence-affected neighborhoods. 


\section{METHODOLOGY}

This paper is drawn from a larger project on young people's peace-building citizenship learning opportunities, comparing those embedded in their lived experiences with those in implemented classroom curricula. It is based on a series of focus group discussions with teachers and students in purposively selected public schools - three in a central Canada city, four in two Bangladeshi cities, and four in a north-central México city. The focus in all contexts is grades 5-9 (age 10-15) — an age at which violence may be confronted directly, yet most students are still in school. All schools were located in economically marginalized areas suffering from substantial amounts of direct violence. The other criterion for school selection was that several classroom teachers expressed interest in working to improve their peacebuilding and/or citizenship education practice. Within each school in each country, participants were 4-6 teachers, and at least 12-15 upper elementary or intermediate students (in small groups) from their classes. Teacher and student focus groups identified, and reflected on the sources and potential citizen responses to, various social conflict situations that concerned them. This paper focuses on the findings from teacher focus groups in the first three (of four) participating Mexican schools. L1 is a telesecundaria middle school; L2 and L3 are elementary schools. All participating teachers worked in self-contained, multi-subject classrooms. ${ }^{1}$

The first fieldwork stage (reported on in this paper) in all contexts involved a series of three (90 minute) focus group discussions with teacher participants in each school. The teachers were invited to describe their existing beliefs and pedagogical practices in relation to citizenship, social conflict and violence. Second, they chose and refined a set of images representing local and larger-scale social conflict problems they considered relevant to diverse students in their particular school community, which researchers later used as prompts in focus groups with students.

Figure 2. Examples of Discussion Prompts

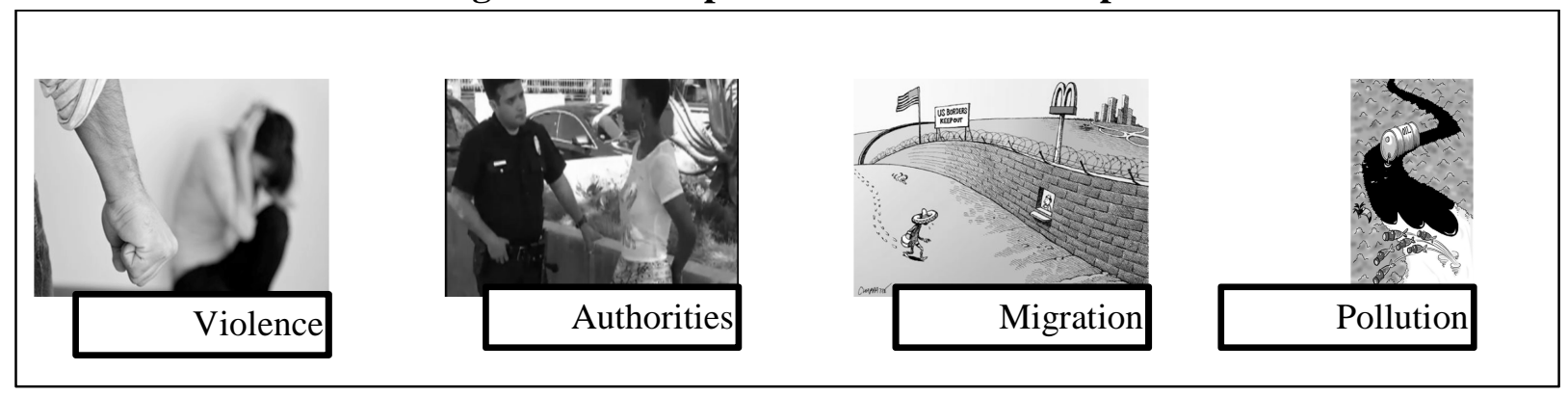

\footnotetext{
${ }^{1}$ Pseudonym codes refer first to the school (L1, etc.), then to the teacher (Docente 1, D2, etc.), then to which session in the series of focus group meetings (FG1, etc.).
} 
Each round of qualitative data analysis has informed future data collection and analysis (CHARMAZ, 2000). An evolving rubric to examine participants' understandings, derived from the literature and earlier rounds of analysis, examines how participants discerned multiple points of view, distinguished violence from the conflicts that underlay and caused them, and expressed a sense of agency (or hopelessness) for citizenship participation in addressing such problems. We juxtapose the teachers' conceptions and concerns with the curricula they reported implementing in their classrooms.

\section{FINDINGS: TEACHERS' CONCEPTIONS AND REPERTOIRES ABOUT CONFLICT AND VIOLENCE}

In our first two focus group sessions at each school, we asked teachers about a series of images depicting various social conflicts we proposed for discussion with their students (examples above, Fig. 2), and about what and how they were teaching relevant to educating for peace and citizenship. Teachers also explored their comprehensions, feelings and repertoires of alternatives regarding the conflicts they chose. This discussion allowed us to see how these teachers viewed their own agency to face these conflicts, as teachers and as citizens.

\subsection{Expressions of direct violence}

Teachers in the three schools coincided in their concern with the pervasiveness in their students' lives of gendered and domestic violence, gangs and insecurity in the neighborhoods, and aggression and bullying in school. Most of them blamed individuals and families, especially male parents -in connection to alcohol and drug abuse, as those who caused patterns of domestic violence and sexual abuse. Many condemned machismo culture, but some also placed responsibility on women for allowing or legitimizing male violence. Similarly, when discussing the role of gangs in students' lives-a major concern expressed in all schools - many also framed these as rooted in careless families and ganginvolved male parents:

"This father ... continues solving his problems in the family with violence. The reality is that families are broken. Children are 14 years-old, 14 years in broken families" (L1-D4-FG2).

"Families tend to be broken; students see the way their parents change partners" (L2-D2-FG1).

As a result, teachers were skeptical and often dismissive of what families could contribute, seeing them more as escalators of violence than as participants in possible solutions:

${ }^{2}$ All field notes and quotes are translations from Spanish by the authors. 
"It's their parents' fault for not educating them... that students do not recognize authorities ... Students are aggressive because parents allow them to be so ... If parents understood this, they would come out and control or defend their children [from gangs]" (L3-D2-FG3)

Beyond family and local culture conditioning, participating teachers identified individual traits of the students themselves, such as selfishness or lack of emotional selfcontrol, as causes of violence. As we will see in their teaching practices below, most of these teachers saw their task as changing students' "mentalities" (rejecting what they had learned at home and in the neighborhood) and creating "safe environments" by making sure students followed rules, obeyed and respected authorities. A few teachers, however, expressed some disagreement with this individualistic, private-family-rooted understanding of aggression problems. Some, albeit fewer, pointed toward risks based in inadequate housing and labor exploitation such as parents' childcare impeded by requirements to work too many hours:

"When a person is aggressive, they act that way because they need to fulfil their needs... We also see it with our students. It's not so much that they are violent people. Their behavior is a reflection of the needs they have to meet... I have highly educated [well-behaved] children, but being outside [the school] is complicated... It's not their fault, nor their families, but society" (L1-D6-FG3).

Nobody mentioned the school role in exacerbating students' behavior or situations of vulnerability, except that a couple of elementary teachers mentioned encouraging a respectful school environment to reduce violence. A few spoke occasionally of encouraging collaborative activities and dialogue to resolve conflicts and foster tolerance in the school.

\subsection{Conflicts rooted in cultural narratives: a 'bad' neighborhood}

Teachers made general statements about teaching children to respect and value diversity, but remarkably did not delve into particular conflicts of ethnic inequities or gender discrimination, although students did raise these issues in their focus groups (BICKMORE et al., forthcoming 2017). However, a related topic that emerged (particularly in the intermediate school, L1, also in L2) was the stigmatization of the neighborhoods surrounding their schools. Some teachers argued it was unfair that their students were "discriminated against" when seeking jobs or opportunities in the city. Some of their colleagues, in contrast, blamed students for projecting bad images, for instance through the ways they dressed:

D2: "It depends a lot on what you want to project... in their way of dressing: girls show everything they can to feel sexy, men with pants half-dropped. If they dress like that to look for work, no wonder they lose jobs."

D4: "Sometimes not just because they are badly dressed, but only because they come from [this neighborhood], they are stigmatized. [Potential employers] think people murder here. Spaces are... stereotyped, as well as the people who live in this neighborhood. 
D6: "Social classes are marked. [This neighborhood] is labeled and opportunities have refused to come [here]... This colony is sadly misjudged; the opportunities that come are scarce" (L1-FG2).

As with direct violence, the teachers suggested few explicit alternatives to deal with diversity/equity issues. Only one teacher in L3 spoke of raising awareness about women's rights, and another mentioned it was important to talk to kids about discrimination.

\subsection{Conflicts with government and authorities}

An issue that emerged as a major concern for a substantial majority of studentsgovernment, especially police, corruption and abuse-was almost absent from teachers' discussions. In school L2, one teacher referred to problems in the justice system, which generated no discussion. When they did mention authorities, some teachers were worried about students' lack of respect for them. A teacher in L3 was concerned that students resisted when the police had to arrest someone in their family (FG3). Only one teacher, in L2, directly said that it was important to encourage students to express disagreements to and about authorities. In general, as with the questions of cultural bias above, police and government abuse of authority was mainly ignored by these teachers, despite its profound effect on their students' lives.

\subsection{Structural Interest Conflicts Rooted in Inequity: Intractable Transnational $\underline{\text { Harms }}$}

One of the most relevant findings for us, was that the vast majority of conflicts teachers chose to discuss, besides those related to direct violence, had to do with transnationally and socially structured interest conflicts, in which wants and needs are not met because of inequitable structures of distribution in society (ROSS, 2010). Issues prominent in focus group discussions were (em)migration, pollution, drug trafficking, poverty, and labor exploitation.

Teachers were mostly unwilling to discuss drug trafficking, though it is a prominent problem in the country that students experienced intensely in their daily lives. In one school they did not mention it at all; in the other two, two teachers offered a couple of sentences, such as, "A student wants to join the 'narcos' to own a jeep and have a better life" (L2-D4FG2). When the drug trade was mentioned, teachers diverted discussion (and lessons) to drug consumption and addiction, again tackling the individual rather than addressing wider social processes. Perhaps being polite to their interviewers, teachers never mentioned transnational dimensions of drug trafficking problems.

Similarly, despite the transnational dimensions of other relevant societal problems such as emigration and pollution, teachers often explained their causes as deviant or unwise individual behaviors. Accordingly, when asked about possible solutions or alternatives to 
these conflicts, teachers did not mention political decision-making. Instead, they emphasized the need to shift peoples' minds and attitudes so that they would choose another path.

For instance, discussing an image of an industrially polluted river (see Fig.2), an issue intensely experienced locally, teachers suggested teaching students to not throw garbage in the schoolyard (L2-D5-FG2), promoting recycling (although none of the schools had recycling bins; L3-TFG2-D1; L1-D5-FG2), or the value of respecting nature (L2-FG2). Only D2 in school L2 mentioned concern with the polluted air they breathed daily, spewed by neighborhood factories.

Likewise, high rates of legal and illegal emigration from the community to North America was a very pervasive transnational issue affecting all students' lives. Yet teachers talked about changing students' mentalities, to make them more committed to finishing their studies and staying in their country (L1-D2-FG2). Teachers clearly recognized emigration as a consequence of the country's economic situation, but responses included one teacher commenting that fathers preferred to leave their children out of convenience (L3-D5-D1), while in L2 they did not discuss this issue at all.

When discussing poverty and labor exploitation, teachers did acknowledged wider social injustices and scarcity of opportunities. In school L2, they expressed concern about students' malnutrition and lack of access to adequate affordable food due to parents' low salaries and unemployment. Yet, even here-reinforcing Young's argument-some of the teachers expressed their desire for students to have a more responsible, hard-working selfcare attitude.

\section{TEACHING PRACTICES: ADDRESSING TRANSNATIONAL DIMENSIONS OF SOCIAL CONFLICTS?}

We asked participating teachers to share examples of their classroom teaching regarding citizenship education and conflict management. Consistent with Nixon's theory, they struggled to make sense of complex, large-scale transnational features of the 'slow' but harmful conflicts experienced by their students. Most participating teachers addressed a few elements of social conflict and/or democratic citizenship education in their teaching, although few had explicitly taught skills or processes for nonviolent conflict analysis, dialogue, resolution, or decision making. Much of this work was based on the textbooks for Spanish, History and Civics/Ethics Education. Some teachers' repertoires for addressing conflict in the classroom apparently emphasized (self-)control; others emphasized dialogue; a few addressed autonomous democratic action although not frequently or in depth. 


\subsection{Educative Peacekeeping: Teaching Personal Responsibility and Values}

Participating teachers widely shared the consideration that the best they could do for students was to teach them values and attitudes toward taking personal responsibility and, individually, not enacting violent behaviors, pollution, or emigration. They consistently showed loving attitudes towards their students, but sometimes had, at the same time, low expectations about what they could achieve. The main approach for these teachers was less to build academic or democratic agency than to teach values to make student attitudes and behaviors more responsible and compliant:

Teachers argued that dialogue and values education, for instance teaching one value each month, could help to "straighten the paths" of students (L2-D5-FG4). L3 teachers reported teaching students values as a way to diminish violence, linking this with selfaffirmation, self-regulation and developing the motivation to improve as individuals: D1 mentioned that she taught students values to prevent them from joining gangs; D2 said they discussed gangs in the context of the 'social conflicts of our society' lesson in the Civics/Ethics textbook (FG1). In FG3, D6 also reported teaching Science lessons on the value of respect for nature (not littering, not hurting trees). Similarly, at the other elementary school, a teacher described teaching students to be responsible/caring towards animals and the environment (L2-D5-FG3).

Clearly, values education was employed not only to tackle interpersonal aggression, but also as a response to structural issues such as environmental degradation. Citizenship education was thus moralized and individualized. Teachers in the same focus groups also described values education as a means to help students engage in peaceful resolution of conflicts:

An elementary teacher explained that, in the beginning of the academic year, she drew a cloud in which she wrote various values, such as respect, love and democracy. Each student posted, on a 'raindrop' paper, a way they had enacted those values. When there was a conflict in the classroom, she pointed to this poster in guiding students to look for a (self-control) solution (L3-D5-FG1).

One of the few participating male teachers mentioned that, when one day there was a conflict between two students, he asked them to establish a dialogue in which he acted as an observer. After these students solved their problem and asked each other for forgiveness, the teacher wrote their names on the class "values calendar" (L3-D3-FG1).

Teachers considered it important to teach children to control their emotions, improve their self-esteem, and care for their bodies:

In elementary school L2, there was particular concern with how sexual abuse and anger were affecting students. D1, D3, D4, and D5 described guiding their students to reflect on values of selfcontrol and respect. A teacher asked students to write in their notebooks those actions that 'make them get angry', then in another column 'what they can do to self-control that feeling' (L2-D3-FG2). Another teacher guided her students to analyze their actions using a chart: how they reacted, and how 
they could have reacted more positively: "this activity helps them understand that they can choose, they can analyze which is the best action to follow and assess the consequences of their actions" (L2D1-FG2). Another taught students to "respect their bodies and those of others" (L2-D4 -FG1). Two teachers wished for the support of psychologists and health professionals to work with parents and students on such issues (L2-D1\&D2-FG4).

Teachers continuously argued for the importance of their students becoming 'more conscious' of their individual faults and choices. As Call-Cummings and Hook (2015) argue in their analysis of two peace education programs in Peru and Jamaica, such calls for 'conscientization' may not be empowering at all, but rather a form of knowledge reproduction. Certainly, participating Mexican teachers' statements took the form of cultural gatekeeping: schools serving as 'civilizers,' dismissing youths' cultural backgrounds and encouraging their appropriation of hegemonic values.

For these teachers, the point of addressing values was to contradict students' cultural backgrounds, the faults and deficits they brought from home. This concern with values transmission, personal responsibility and cultural gatekeeping is consistent with teachers' distrust and blaming of families. They ignored conflicts' political and justice dimensions and public/social responsibilities. This gentle approach to peacekeeping control naturalizes the persistence of social injustices as the unavoidable result of bad or irresponsible choices made by individuals and families.

\subsection{Citizen Security in the school: Convivencia or control?}

Many participating teachers tended to minimize risk by avoiding, curtailing, or omitting any inquiry or discussion of difficult conflictual issues in their classrooms. This confirms prior findings on Mexican curricula and teaching, that opportunities to explicitly work with conflicts are quite low (BASCOPÉ ET AL., 2015; REIMERS, 2007). Most of the teachers participating in our project tended not to teach explicitly about conflict or conflict resolution. While some issues were mentioned in class, especially in relation to textbook lessons in the new Civics/Ethics course, students and teachers themselves described them as tangential to learning expectations. Some teacher participants explicitly recognized what they saw as the impossibility of dealing with certain issues, such as drug trafficking; others ignored the possibility of openly discussing issues, such as domestic violence. A few of these teachers did mention some social conflicts fairly often in single lessons or short conversations, although opposing viewpoints, evidence, or solution alternatives were rarely pursued:

In FG3 at the intermediate school, the facilitator asked whether teachers considered it possible to address controversial subjects such as drug trafficking.

D5: "Sometimes touching on these issues is taken as a taboo... Sometimes [some teachers here] talk about things, do not give names but put it in the third person. Sometimes it is difficult, because they 
feel that they will be uncovered and will get in trouble. It is difficult for students to participate and talk about [such issues]."

D6: "It is not possible; it is a sensitive issue... In my case, I would not do it" (L1-FG3).

Such avoidance of conflictual issues is a careful response to environmental factors that make it difficult to address controversial topics at school—such as some students' membership in gangs or even the safety of their teachers. Yet, as Michael Apple (APPLE, 1978) has argued, avoidance of conflicts and critical perspectives, or attempting a 'neutral' stance, is one of the main ways in which hegemony and privileges are reproduced through schooling (BICKMORE, 2012).

A more explicit dimension of the citizen security approach was teachers' substantial concern with instilling respect for rules, norms and authorities. A small proportion of these teachers addressed conflicts involving students through in-class or private discussions. In contrast, most of their colleagues sought to control escalation of conflicts by demanding rule compliance rather than addressing the problems, feelings, or relationships involved. Such control measures are supported by government safe schools (framed as convivencia) policies and programming:

An intermediate teacher described a lesson activity on social sanctions (authority): “...through educational materials such as 'word search' and crossword puzzles, [students] find the word and write up a text on the importance of that value for daily life, or about people who represent authority and why it is important that these people sanction them" (L1-D3, FG1).

Another explained, "The Secretary of Education asks us to be trained on this . . Now there is a new law on education for peace (Convivencia). If bullying happens at school, we work under the new law. Then, 'either you're good in school, or your behavior is reported'... [The new regulation] applies to the whole school community and we need to know it by heart" (L1-D6-FG2).

An elementary teacher described requiring parents to sign the new state Convivencia regulations, promising to help control their children. In the Civics/Ethics course, the same teacher also used the Convivencia law as the reference for an ostensibly student-centered process of establishing classroom rules, such as: "not to hit, not to take away students' sandwiches, etc." (L3-D3M-FG1).

Teachers valued the creation of safe, friendly spaces and environments where misbehaviors and conflicts would not occur. They reported that extra-curricular and community-building activities, enjoyed by students, were particularly effective in this regard:

Intermediate teachers identified activities such as theatre and soccer tournaments as contributing to developing students' tolerance, solidarity, and the "reduction of conflicts, helping in the convivencia of the educational community... For example when they are in the sports class and someone starts to insult others, the teacher stops the activity or ends the game: this has also made them reflect in terms of attitude" (L1-FG1). 
While many of these problems have wider, including transnational, societal dimensions, such as prevalent violence against women and children or the extensive networks of the drug trade, teachers narrowed their focus to individuals: fostering selfregulation, and/or or the punitive path established by state convivencia regulations. The school's taking up these tasks of securitization and management of populations considered at risk and deviant, indicates neoliberal rationalities-an ethical-political ideal-and associated techniques of governance, reaching youth through the school.

\section{FINDING THE CRACKS: PEACEBUILDING (DEMOCRATIC CONVIVENCIA) LEARNING OPPORTUNITIES}

A main purpose of this research has been to identify existing practices, spaces, and opportunities for deeper democratic peacebuilding work in schools. People are not passive receivers or reproducers of structural forces or hegemonic discourses: they interpret, shape, contest, and enact them in different ways. While often participating teachers were reproducing discourses of personal responsibility and individual control, they also put into practice alternative approaches. Below, we highlight instances where some teachers taught toward collective action and agency for democratic peacebuilding. These instances, however, need to be read carefully, because they were not as prominent as the practices and discourses above, and sometimes were ambiguous in their purposes, actual implementation, or potential outcomes. Nonetheless, most participating teachers expressed great desire, especially in the later sessions of the series of focus group conversations, to make democratic peacebuilding education activities an integral part of their daily work, and to develop some of their existing classroom activities into more consistent practices.

\subsection{Dialogue and Peacemaking (Conflict Resolution) Alternatives}

In every school, teachers shared some situations in which they had promoted dialogue for resolving interpersonal conflicts among their students-although not generally including further inquiry about the conflicts' causes, relational dynamics or systemic remedies. While helpful in containing violence, such peacemaking practices imply a negative view of conflict, as something to be avoided or removed more than a learning opportunity. At the same time, peacemaking alternatives do involve student voice and self-governance skills that may scaffold broader-scale democratic peacebuilding (BICKMORE, 2012):

One intermediate teacher described how she taught students to avoid violent escalation of disagreements: "We worked on distinguishing what is violence, what is conflict, what is the disagreement, just because I do not agree with what you say I don't have to punch you" (L1-D2FG3).

In one elementary school, two teachers said they taught students to "use dialogue to solve their own problems" (L2-D4-FG1), and that "the only way to solve issues is by talking about them." One said this conflict resolution learning "sometimes transcends to their homes, and many students ask their 
parents to talk [rather than fight] about their own issues." She also identified a student from her class who, although he belonged to a gang, had stopped being aggressive with his classmates outside the school due to her peacemaking dialogue circles (L2-D4-FG2).

During a "peace week," another teacher asked her students to write a letter to a classmate with whom they had a conflict, telling him/her how they felt and proposing a solution (L3-D5-FG1). Another organized a classroom "debate" on gender equity, after some female students complained about male classmates' aggressive and rude behavior towards them (L3-D6-FG1).

Later in the series of focus groups, another L3 teacher described new conflict resolution procedures he had implemented: telling students in conflict to write down who the stakeholders were, what happened, and possible solutions. Later, with his students, D6M began to analyze the root causes of these conflicts. He realized that he was partly responsible, because students who finished their work first did not have anything to do and, consequently, started making trouble. He also organized round table discussions of some problems, and let student stakeholders decide whether they wanted him, the principal or themselves to be the mediators of peacemaking procedures. Once given this option, his students tended to solve their problems by themselves (L3-D6-FG4).

Beyond dialogue for interpersonal conflict resolution within classroom groups, several teachers showed great interest and care for listening to students' problems and letting them express their emotions in classroom "debates" or discussions of difficult issues. As described, these opportunities to voice experiences or perspectives often did not develop into problem analysis or dialogic exchange across contrasting points of view.

Using Civics textbook lessons, teachers sometimes invited discussion of moral dilemmas, which they sought to connect with students' experiences to provoke reflection on decision alternatives. They also facilitated debates and roundtables to discern positive/negative consequences of issues such as emigration, gangs, hunger, or war. They framed such free expression of ideas, learning to listen to others, and positive expression or control of emotions as "promoting democracy:"

An intermediate teacher shared an example: "A few days ago, [after] I heard a comment over the radio that 'violence has diminished'... I asked my students: Do you think that violence is declining? I do such activities with the aim of gradually making them aware of their reality and the world they face" (L1-D3-FG2).

An elementary teacher asked her students to reflect on the reasons for their hunger: "Why didn't I eat? Most of them tell me that it is because their parents don't have a job. This helps us study social problems such as poverty, lack of employment, lack of investments. This is a problem that exists in the whole country, not only in the community. Based on this kind of discussion, my students get a wider perspective on the problems that they also live" (L2-D2-FG1). Another L2 teacher mentioned that her students felt relieved when they expressed how they felt, and that listening to her students' situations helped her understand why they were not learning (L2-D3-FG3).

Some intermediate teachers invited students to create and perform dramatic skits about lived social conflict issues:

In one play, "the scene is that they are robbing a bank and the police arrive, and their play shows how the police, instead of helping do not help you. They showed the police colluding with the 
thieves. They have a need to communicate what they are experiencing. In theatre, they can express what they feel... they communicate what they are living. They mention that the police arrive when the problem is over or have colluded with the thieves" (L1-D1-FG3).

Thus, teachers had created some student-centered, dialogic learning opportunities that delved into larger scale social conflicts, although rarely their transnational or controversial dimensions.

\title{
7.2. Valuing global diversity: empathy and caring through History, Spanish and
} Geography

Teachers also encouraged students' solidarity and empathy for the diverse situations of others, commonly using the sentence, "put yourself in somebody else's shoes." Sometimes, this work expressed an idealized, celebratory diversity, with little recognition of the power imbalances and hierarchies involved in cultural conflicts.

Many times, teachers taught these issues through examples from around the world, comparing these to their students' own situations. In Spanish class, for example, students might study other countries' cultures to perceive "difference as something that does not limit convivencia, as something that has to be respected and learned from" (L1-D2-FG4). Also in Geography, teachers compared the students' equity situations with those of people in other countries:

\begin{abstract}
An elementary class analyzed poverty related to natural disasters in Nepal and Africa, in comparison with students' own situation of social vulnerability based in economic insecurity and crime (L3-D2FG4). Another teacher showed a video about the quality of life in Africa and in the USA, inviting students to compare these situations to what they themselves had vs. didn't have, and about gender equity and women's rights (L3-D5-FG2, L3-D5-FG4). D2 studied poverty in Africa, Brazil and Mexico. A colleague liked the phrase: 'Think globally, act locally:' "If I'm concerned about hunger in Africa, I cannot solve that problem there, but I can solve problems in my community" (L3-D1FG2).
\end{abstract}

Not least, teachers mentioned guiding students to analyze different perspectives, points of view, decisions made by characters, and worldviews in fiction and history stories. For instance, L2 teachers mentioned probing history episodes to guide students' reflection about the causes of conflicts, and alternative decisions that could help make conflicts get better or worse:

At the end of each history unit, D1 asked his students how they would have solved a given problem (L2-D1-FG1). D4 studied the roles of women at different historical moments, as well as the division of social classes (serfs and feudal lords) in the Middle Ages (L2-D4-FG3\&4). D5 used visual organizer charts to analyze the causes of the Mexican Revolution, and also studied past episodes of poverty and scarcity (L2-D5-FG2\&4). Similarly, another elementary teacher read aloud stories about conflict escalation, discussed and analyzed the characters' aggressiveness, and opened a "debate" to "reflect" about possible solutions that might mitigate the conflicts that arose in the story (L2-D1FG4). 
Thus teachers prioritized the use of conflict examples distant from students' lived experience to shed light on present social conflicts.

\subsection{Collaborative Work, Community Engagement: Citizen and Environmental Issues}

Most of the teachers emphasized their implementation of collaborative student teamwork to help foster communication, cooperation and group responsibility skills. In these teams, teachers mixed students of different academic abilities, as a way to recognize and value the contributions of each one to foster participation and creativity. A few engaged student teams in community issues, especially in environmental science-analyzing situations and suggesting solutions. Environmental issues served as a relatively non-controversial platform to engage students in working collaboratively and practicing some agency in relation to community issues. As said, the transnational dimensions of pollution problems were not mentioned:

Teachers in L1 mentioned a research project doing surveys and proposing plans about recycling in the community: "It was collaborative work: they had to collect the [plastic garbage] and make designs ... How this contributes to peace? It is collaborative work and respect for their research, and listening to how they arrived at these ideas and everything that can harm the community." (L1-D6FG4). A colleague elaborated, "these projects may help students realize they can do things to change, both themselves and their surroundings" (L1-FG1).

L2-D4 hoped to teach her students to be "social actors," to believe that they were capable of raising awareness and making changes. Students had worked collaboratively cleaning up the neighborhood, and with parents in projects to recover green areas (L2-D4\&D5-FG3\&4). In a combined ScienceSpanish unit at the same school, students conducted a project, called "United for the environment of the neighborhood," to examine and propose tangible change solutions to local environmental problems caused by the factories that generate bad odors and pollution (L2-D2-FG2). The teacher hoped to expand this project "by visiting and taking pictures of the damage," having students "visit the mayor," and getting students to locate the community centers and government agencies that could do something about this intensely-felt environmental conflict (L2-D2-FG4).

With regard to 'external' citizen authorities, teachers made minimal reference to political institutions or community networks. They mentioned students writing letters to authorities, but said letters were never actually sent. Significantly, teachers mentioned students' interest in electoral process within the classroom and the potential connection with elections and voting issues in the region and the country. In the few instances described, teachers showed evident hesitation about students' critical engagement in these or other citizen participation processes such as protests.

L1 teachers showed concern that students would replicate patterns of patronage and clientelism, for instance D5's students offering sweets to gain supporters in an election campaign simulation, even though they were not supposed to cast votes. D3, however, had used activities related to elections to elicit students' concerns regarding their material needs, presenting elections as a means to obtain such justice. Later, her students had initiated a voting process to decide upon a play to present in front of the school. D5, however, expressed disapproval that students might choose to protest (L1D3\&D5-FG4). 
Similarly, at L2: "What draws my attention is that they see the solution is to protest or strike. It is what they see on television... Blocking a street is not going to solve anything. So, yes, there is hopelessness, because they think [protest] is the only thing they can do" (L2-D5-FG3).

\section{DISCUSSION AND CONCLUSION: AGENCY AND DEMOCRATIC PRACTICES OF CITIZENSHIP EDUCATION}

As teachers implement global citizenship and convivencia curriculum in this Mexican city, they find themselves confronting an existential contradiction. On the one hand, teach students to believe in democratic institutions and the values they are supposed to embody. On the other hand, recognize that what they teach hardly represents their students' experiences of life under their own 'democratic' regime, with almost no space for students to imagine transnational citizenship roles and solutions to globalized problems. The teachers in this project demonstrated great commitment to improving the lives of their students and yet, as we have shown, the wider hegemonic political context narrows the spaces available for teachers or their students to develop and express strong agency in view of the scale of the problems they face.

Participating teachers' implementation of active and collaborative pedagogiessuch as discussions of moral dilemmas, debates, and historical conflicts—do depart from narrow, 'traditional civics' and its static vision of values and institutions. Yet these 'active pedagogies' seldom sought experiential, collective engagement with wider aspects of social conflicts. The emphasis on citizen security convivencia, promoting peacekeeping through (extrinsic and self) control and values inculcation, reproduces narrow imaginaries of action to confront injustices and social conflicts, such as the transposition of gendered and sexual violence into management of the body and emotions.

Paradoxically, those on the receiving end of globalized slow violence, the global poor, need to take responsibility, internalize values of personal responsibility, and show resilience to overcome the risks and consequences of globalization 'externalities' such as migration, pollution, labor exploitation and poverty. Consequently, youth's local sufferings remain private, not represented in teachers' imaginaries or sample lessons as wide-scale public, political injustices. This is a painful implication of even the gentle, loving, educative forms of citizen security peacekeeping. Such depoliticized and privatized understandings of the 'good citizen' as passive and alienated from global human relations, structural power dynamics and collective action, in turn, present enormous challenges for teachers and their students, in facing the daily anxieties of conflicts, violence and injustices in and beyond school life. These dynamics point in exactly the opposite direction from an active engagement in democratic life.

Citizen agency is reduced to responsible, law-abiding, local-only individual behaviors. Nowhere is this more evident than when we examine the ways teachers 
understood their roles in face of transnational conflicts such as pollution and drug trafficking. The violence embedded in these dynamics are intensely lived by these communities, yet their scale, temporality and spatiality make them so overwhelming that the possibility of seeing themselves as participatory actors in their transformation was reduced to individual good behaviors: abstaining from aggression, recycling awareness, avoiding drug consumption. This indicates clearly unequal access to any sort of 'global' democratic citizenship through these curricula.

Therefore, it should not come as a surprise that teachers in these marginalized contexts express anxiety about what their endeavors might achieve. Despite committed efforts in citizenship and convivencia education, feelings of hopelessness and disenfranchisement arise among them. They are 'good teachers' and 'good citizens,' insofar as they do as much as they can with what they are given. But, at the same time, they are trapped in a tension between their role as cultural gatekeepers/peacekeepers and their desires to empower their students.

This tension increases as citizen security-oriented school convivencia policies thicken the barriers between teachers and students, and between the school and the community. While teachers told us that their students' neighborhoods are stigmatized, they themselves face the difficulty of being insiders/outsiders of such neighborhoods, representing the voice of the 'civilized' society against the manifest injustices they know their students live. In the end, we should ask ourselves whether citizen disengagement isfar from being a product of disinterest or apathy - a result of populations being pushed away from the democratic possibilities of participating in the voicing and resolution of their own conditions of injustice.

Neoliberalism represents a moral philosophy that evidently pervades the implicit and explicit curricula at schools. It elicits a certain ideal of moral responsibility focused on the entrepreneurial and prudent individual and the self-controlling, self-caring body: flexible but obedient, individually mobile, only loosely tied to the community, competitive, embracing freedom and self-realization but dismissive of social bonds. The school in a marginalized community extends neoliberal techniques of governance over supposedly deviant and risky populations-delegating this task to teachers. These populations become, as Young and Nixon argue, the focus of governance and the main receivers of harm and 'responsibility,' with little opportunity for agency.

This paper illuminates, in the voices of committed teachers in one part of the global periphery, some of the large scale, complex relational entanglements of contemporary forms of slow violence (NIXON, 2011), the political (human made) character of inequities, and the particular responsibilities and options for action demanded by these various scales of transnational relations (YOUNG, 2011). Eventually, these conceptualizations may help 
youth and their teachers to imagine and devise more effective, contextually relevant citizenship education, to challenge their conditions in the global world. A global citizenship education that starts from youths' positional lived experiences with transnationalized social conflicts could provide those at the receiving end of the negative consequences of globalization with opportunities to challenge and change dominant narratives of their own history.

\section{REFERENCES}

ACEVEDO RODRIGO, A., and LÓPEZ CABALLERO, P. (2012): Ciudadanos inesperados : espacios de formación de la ciudadanía ayer y hoy (México, D.F., El Colegio de México, Centro de Investigación y de Estudios Avanzados).

ANDREOTTI, V. (2015): Global citizenship education otherwise: pedagogical and theoretical insights, In A.A. ABDI et al., Decolonizing Global Citizenship Education, pp. 221-230 (Rotterdam, SensePublishers).

APPLE, M.W. (1978): Ideology, reproduction, and educational reform, Comparative Education Review, 22, pp. 367-387.

BASCOPÉ, M., BONHOMME, M., COX, C., CASTILlO, J.C., AND MIRANDA, D. (2015): Curricular guidelines and citizenship attitudes in Latin American Students: a comparative analysis, Revista Latinoamericana de Ciencias Sociales, Niñez Y Juventud, 13, pp. 1169-1190.

BICKMORE, K. (2011a): Education for "peace" in urban Canadian schools: Gender, culture, conflict, and opportunities to learn. In P.P. TRIFONAS, AND B.L. WRIGHT. (Eds.) Critical Issues in Peace and Education, pp. 88-103 (New York, Routledge).

BICKMORE, K. (2011b): Policies and Programming for Safer Schools: Are "Antibullying" Approaches Impeding Education for Peacebuilding? Educational Policy, 25, pp. 648-687.

BICKMORE, K. (2012): Peacebuilding Dialogue as Democratic Education. In H. CREMIN, and J. ARTHUR. (Eds.) Debates in Citizenship Education, pp. 115-131 (New York: Routledge).

BICKMORE, K. (2014a): Peacebuilding Dialogue Pedagogies in Canadian Classrooms, Curriculum Inquiry, 44, pp. 553-582.

BICKMORE, K. (2014b): Citizenship education in Canada: "Democratic" engagement with differences, conflicts and equity issues? Citizenship Teaching \& Learning, 9, pp. 257-278.

BICKMORE, K., AND MACDONALD, A. (2010): Student leadership opportunities for making "peace" in Canada's urban schools: Contradictions in practice, Interamerican Journal of Education for Democracy/ Revista Interamericana de Educación Para La Democracia, 3, pp. 126-152. 
BICKMORE, K., AWAD, Y., AND RADJENOVIC, A. (2017): Voices of Canadian and Mexican Youth surrounded by violence: Learning experiences for peace-building citizenship, Research in Comparative and International Education (Theme Issue: Revisiting Peace Education: Bridging Theory and Practice).

BIESTA, G. (2009): Sporadic democracy: Education, democracy, and the question of inclusion. In KATZ, M.S., VERDUCCI, S., AND BIESTA, G. (2009). Education, Democracy, and the Moral Life pp. 101-112 (Dordrecht: Springer Netherlands).

CALL-CUMMINGS, M., AND HOOK, M.R. (2015): Endorsing empowerment? A critical comparative study of peace education in Jamaica and Peru, Journal of Peace Education, 12, pp. 92-108.

CARBAJAL PADILLA, P. (2013): Convivencia democrática en las escuelas. Apuntes para una reconceptualización, Revista Iberoamericana de Evaluación Educativa, 6, pp. $13-35$.

CARRETERO, M., HASTE, H., AND BERMUDEZ, A. (2016): Civic Education. In Handbook of Educational Psychology, pp. 295-308 (London: Routledge Publishers).

CHARMAZ, K. (2000): Grounded theory: objectivist and constructivist methods. In DENZIN, N.K. AND LINCOLN, Y.S. (Eds.), Handbook of Qualitative Research, pp. 509-535 (Thousand Oaks, Calif: Sage Publications, Inc.).

CHÁVEZ ROMO, M.C. (2014): La estigmatización de la adolescencia como grupo poblacional en riesgo y sus repercusiones en la construcción de ciudadanía, Sinéctica, pp. 1-17.

COX, C., JARAMILLO, R., AND REIMERS, F. (2005): Educar para la ciudadanía y la democracia en las Américas: Una agenda para la acción (Washington, D.C.: Banco Interamericano de Desarrollo).

COX, C., BASCOPÉ, M., CASTILlO, J.C., MIRANDA, D., AND BONHOMME, M. (2014): Citizenship education in Latin America: priorities of school curricula, IBE Working Papers on Curriculum Issues.

DAVIES, L. (2008): Interruptive democracy in education. In ZAJDA, J.I. et al., Comparative and Global Pedagogies: Equity, Access and Democracy in Education, pp. 15-31, (Dordrecht: Springer).

DÍAZ-AGUADO, M.J. (2002): Por una cultura de la convivencia democrática, Revista Interuniversitaria de Formación Del Profesorado, pp. 55-78.

FIERRO, M.C., TAPIA, G., FORTOUL, B., MARTÍNEZ-PARENTE, R., MACOUZET, M., AND MUÑOZ-LEDO, M.J. (2013): Conversando sobre la convivencia en la escuela: Una Guía para el auto-diagnóstico de la convivencia escolar desde las perspectivas docentes. Revista Iberoamericana de Evaluación Educativa, 6, pp. 103-124.

GALTUNG, J. (1969): Violence, Peace, and Peace Research, Journal of Peace Research, 6, pp. 167-191. 
GALTUNG, J. (1976): Three approaches to peace: Peacekeeping, peacemaking, peacebuilding. In GALTUNG, J. (Ed.) Peace, War and Defense: Essays in Peace Research (Volume 2), pp. 297-298 (Copenhagen: Christian Ejlers).

GUEVARA NIEBLA, G. (2012): México 2012: la reforma educativa (México, D.F.: Cal y Arena).

HAKVOORT, I., AND OLSSON, E. (2014): The School's Democratic Mission and Conflict Resolution: Voices of Swedish Educators. Curriculum Inquiry 44, 531552.

IEP, INSTITUTE FOR ECONOMICS AND PEACE (2015): Mexico Peace Index 2015: Analyzing the Changing Dynamics of Peace in Mexico (Retrieved from http://economicsandpeace.org/wp-content/uploads/2015/06/Mexico-Peace-IndexReport-2015_1.pdf), accessed August $7^{\text {th }} 2016$.

MORRISON, B.E., and VAANDERING, D. (2012): Restorative Justice: Pedagogy, Praxis, and Discipline, Journal of School Violence, 11, pp. 138-155.

NIETO, D. (2012a): Democracia y Conflicto: Las contribuciones del pluralismo agonista. In SILVA VEGA, R et al., Desafíos Para La Democracia Y La Ciudadanía, pp. 103145 (Cali: Universidad Icesi).

NIETO, D. (2012b): Neoliberalism, Biopolitics, and the Governance of Transnational Crime. Colombia Internacional, 76, pp. 137-165.

NIXON, R. (2011). Slow violence and the environmentalism of the poor (Cambridge, Mass.: Harvard University Press).

O’MALLEY, P. (1996): Risk and responsibility. In BARRY, A. et al., Foucault and Political Reason : Liberalism, Neo-Liberalism, and Rationalities of Government, pp. 189-207 (Chicago: University of Chicago Press).

PEETZ, P. (2011): Youth Violence in Central America: Discourses and Policies, Youth \& Society, 43, pp. 1459-1498.

REIMERS, F. (2007): Civic Education When Democracy Is In Flux: The Impact Of Empirical Research On Policy And Practice In Latin America, Citizenship Teaching and Learning, 3, pp. 5-22.

ROSS, M.H. (2010): Peace Education and Political Science. In SALOMON, G. et al., Handbook on Peace Education, pp. 121-133 (New York: Psychology Press).

RUITENBERG, C. (2010): Conflict, affect and the political: On disagreement as democratic capacity, Factis Pax, 4, pp. 40-55.

YOUNG, I.M. (2011): Responsibility for justice (New York: Oxford University Press).

ZURITA RIVERA, Ú. (2013): Las Escuelas Mexicanas y la Legislación sobre Convivencia, Seguridad y la Violencia Escolar, REYTE, 2, pp. 19-36. 


\section{PROFESIOGRAFÍA}

\section{Diego Nieto}

Doctoral student, Curriculum Studies and Teaching Development. Comparative, International and Development Education. Ontario Institute for Studies in Education, University of Toronto. Datos de contacto: Ontario Institute for Studies in Education, University of Toronto. 252 Bloor Street West (room 10-170) Toronto, Ontario M5S1V6 Canada. E-mail: danietosa@gmail.com

\section{Karthy Bickmore}

Professor, Curriculum Teaching \& Learning. Comparative International Development Education. Ontario Institute for Studies in Education, University of Toronto. She teaches graduate and teacher education in comparative democratic citizenship and conflict/peacebuilding education, and critical curriculum studies. Current research examines gaps (and potential links) between young people's lived experiences of citizenship and what/how they are taught in public school, in neighborhoods experiencing violence, in Canada, Mexico, and Bangladesh. She is Guest Editor of Curriculum Inquiry theme issue (44:4 September 2014) on Peace-building (in) Education: Democratic Approaches to Conflict in Schools and Classrooms, and Co-Editor of Comparative and International Education: Issues for Teachers (revised edition forthcoming 2016). Recent chapters appear in Teaching Global Matters in Local Classrooms (OISE 2014), Restorative Approaches to Conflict in Schools (Routledge 2013). Datos de contacto: Ontario Institute for Studies in Education, University of Toronto. 252 Bloor Street West (room 10-170), Toronto, Ontario M5S1V6 Canada. t. (+1) 416-978-0237 E-mail: k.bickmore@utoronto.ca

Fecha de recepción: 12 de agosto de 2016.

Fecha de aceptación: 22 de diciembre de 2016. 